\title{
Library-Book Trade Relations in the Field of Current Books
}

I T IS APPARENT TO ANYONE who cares to look into the matter that, strangely enough, library literature pertaining to the field of acquisitions is meager. This is especially true of the phase of acquisitions related to purchasing. Consequently, the subject of librarian-bookseller relationships has been woefully neglected in the writings and discussions of the library world.

What little has been said about the interdependence of librarians and booksellers has usually revolved around those aspects of the trade related to out-of-print and rare books. The current book trade, both domestic and foreign, comes up less frequently as a subject for consideration. Surely this cannot be attributed to any lack of common meeting ground between the librarian and bookseller. What librarian at all concerned with acquisitions, or what dealer in current books, is not interested in ordering, service from suppliers, invoices, discounts, claims, elusive materials, files of outstanding orders, continuations, bibliographical work, personnel problems, administration, to name the more obvious matters?

The librarian tries to devise the most efficient method of ordering; the bookseller does the same. The librarian demands invoices from the bookseller which are accurate, made out as requested and presented with the utmost speed; the bookseller makes the same demands

Mr. Coppola is chief, Library Service, Stechert-Hafner, Inc., New York. This paper was presented before the Acquisition of Library Materials Board, Philadelphia, July 8, 1955. of the publisher. The librarian requests efficient, prompt service from his bookseller; the bookseller requires the same of his publisher. The librarian seeks the best possible discount from his bookseller; the latter does the same from the publisher. The librarian must follow up his orders by maintaining files for outstanding requests and by devising efficient claim procedures; the bookseller, if he is to operate efficiently, must do likewise. The efficient librarian should do some bibliographical searching in conjunction with ordering; the expert bookseller must often do likewise. The librarian must entice professional and subprofessional help and devise sundry ways of keeping his people; the bookseller, too, must concern himself with personnel and its problems. The capable librarian should combine bookmanship and administration; the successful bookseller must do so.

But this labors the point. One need go no further to demonstrate that technical processes in libraries parallel the activities of a bookselling organization. If, then, the librarian and the bookseller use so many similar if not identical procedures, certainly a frequent exchange of ideas is in order. Both stand to profit from better communication. The librarian can transmit ideas which will enable the bookseller, who is in a way an extension of the acquisitions department, to provide better service. The bookseller can offer suggestions which would not only make his own task easier but would result in greater efficiency. Improving communication between the two would redound, in the end, mostly to the advan- 
tage of the librarian. Certainly, for the librarian, such exchange of thought would throw more light upon the book market, which to quote our chairman, Mr. Vosper, "is an important subject not adequately understood by most librarians."

Time does not permit a full scale discussion of the various phases of librarianbookseller relationships. However, a few minutes can be devoted to several topics of common interest, which may lead to an exchange, if not of ideas, at least of some information.

For example, take the subject of current American publications. The librarian today can place his order for such books with four different types of suppliers: (1) the publisher; (2) the local bookseller; (3) the large general bookseller or library agent, usually located in the metropolitan areas; and (4) the jobber.

Depending on circumstances, the 'librarian may find it to his advantage to use each of these agencies. If he is interested in consolidating his orders, with economy in mind, he must turn either to the jobber or to the large general bookseller. The jobber will allow the better discount; the large general bookseller will not grant a high discount, but he will provide better service in out-of-the-way, non-trade, and out-of-print titles.

The librarian not too concerned with consolidation of orders may perhaps rely upon several or all four agencies. Obviously, the more sources from which the library orders the greater will be the work-load of that library: more invoices, more correspondence, expenses of one kind or another. Incidentally, when a librarian splits his orders, he should, for the good of all concerned, keep in mind that his demands for service should not be unreasonable. If he allots only the elusive and short discount material to the bookseller best equipped for it, would it not be wise to favor that same bookseller every so often with orders for some profitable material as well? This leads us to the question of discounts.

One cannot criticize the librarian for seeking the best terms possible on domestic publications. Nevertheless, blind insistence on discounts to the exclusion of all other considerations does not make for a sound bookselling economy. Surely, such an economy is vital to the acquisitions librarian who needs ever-improving service from the bookseller. Consider, for example, the case of the library agent. The large general bookstore, or library agent, willing and able to handle most any type of order, has all but disappeared from the scene, simply because he could not meet the discounts offered to the librarian by jobbers and publishers. By buying directly from both these agencies at high discounts and not from a retailer, such as the library agent, the librarian has been directly responsible for the virtual elimination of that type of bookseller from the picture. As a consequence, the librarian may soon be forced to split his orders even though at times he may prefer not to do so. The gain in discount in many cases, if carefully measured, may prove to be negligible in relation to the loss of services. Furthermore, a library agent can be of help in many different ways. For example, there is one important library which, having complete faith in its library agent, has recently arranged to receive one annual invoice, not itemized, for many of its foreign periodical subscriptions, with the understanding, of course, that it can obtain itemized information upon request. How much time, trouble and expense such a procedure can save!

The continued placement of such a premium on discounts could conceivably result in a dangerously unhealthy situation in the book industry. If large bookselling concerns are forced into a precarious financial condition, it will most assuredly not be to the advantage of the librarian. Certainly the picture is not exaggerated. Witness how few concerns that 
are booksellers in the true sense of the word are left in the United States today. This is a situation quite contrary to that existing in most European countries.

Another subject of possible interest to librarians and booksellers is that of foreign publications. Librarians who purchase current foreign books through booksellers find a rather ideal situation today, especially if the publications are from Europe. Many order directly from the country of publication. Others order from American agents. According to John Fall: "In general it will be found that the American dealer is aware of foreign competition and that he has adjusted his prices to conform to European prices or even to improve on them." 1 American dealers have facilities in other areas of the world also, much to the librarian's advantage. These dealers often employ persons who are acquainted with a number of foreign languages, and they may have foreign offices staffed with local personnel. The importance of dealing with publishers and bookmen abroad in their own tongue and, in so far as possible, according to their own patterns, should not be underestimated.

Among various special aids to libraries, the American importer can often arrange to bind the paper-back foreign books before delivery. When there are several editions available of particular titles, he can at times choose the one most suitable for library use.

In skimming over the subject of foreign books, one would be remiss not to mention the valuable service which dealers in foreign books provide through their periodic lists and catalogs of new publications. Even from countries where bibliographies are good, any news of books and periodicals should be invaluable to the librarian. Often such announcements will offer detailed descriptions, and will call attention to items far in advance of publication. These titles may not appear

1 John Fall, "Problems of American Libraries in Acquiring Foreign Publications," Library Quarterly, XXIV (1954), 101-13. until much later in the regular bibliographies and then often with a paucity of information.

The bookseller is much concerned with library order procedures, whether for foreign or domestic publications. $\mathrm{He}$ is interested first in the bibliographical information which the librarian supplies, and second in the form in which the order is placed.

Although the bookseller is equipped to supply or add to the bibliographical information on an order, certainly this should be no reason for leaving out any available data, especially if it happens to be right on hand, when the order is prepared in the library. Why do some librarians neglect to mention when ordering that a particular book is known to be out of print? Obviously it makes all the difference in the way the bookseller will handle that order. The bookseller will deplore any trends in libraries which seek to cut down on essential bibliographical work performed before a title is ordered. The librarian who is primarily interested in getting the book should know that whatever information he can contribute will increase the chances of obtaining it, as well as speed up delivery.

It is surprising to see how often a title may be reported unknown or out of print by harassed or understaffed booksellers simply because the librarian did not take the trouble to establish the correct name of the author. The expert, well-staffed book concern will endeavor to avoid this, but it may receive the order only after others have had it and after much time has been lost. Actually, the dealer does not require too much data. He will be happy if he can at least have the author's name in correct form, the name of the publisher, and the place of publication for some of the foreign titles. Of course, in the case of smaller libraries with inadequate sources of information, asking for even such rudimentary facts may at times be unreasonable.

The manner in which orders are 
placed, thanks to the introduction of multiple order forms, has received quite a bit of attention in the library world in recent years. The bookseller is indebted to the librarian for introducing this new procedure. $\mathrm{He}$, too, in many instances, now does his ordering in the same way. However, some of the library forms seem not to have been designed with much consideration for the bookseller. It behooves the librarian who is about to adopt a multiple-form system to help the bookseller if he can, for then he will be repaid with better service.

What the bookseller wants above all is a 3" $\times$ 5" slip, simple in design. He would prefer not to receive the eighth or ninth copy and would be delighted with the first. Having the library's name on the top, instead of anywhere else on the slip, is preferable. Certainly he looks askance at those multiple order forms that are accompanied by a covering letter bearing necessary information which does not appear on the order forms themselves. $\mathrm{He}$ himself is then obliged to transcribe such data, relating (for example) to fund or blanket order number, to each slip. Nor is he pleased with an arrangement whereby he is required to return his one and only form when he supplies the book. In such cases he is left without an original record and must, if he is to operate intelligently, make a copy for his own files. Why not furnish the bookseller a form in duplicate if one copy must be returned to the library?

Surely something can be done to standardize the myriad of forms now in existence. The bookseller and the librarian, we are sure, welcome the suggestion which appeared in a recent issue of the Journal of Cataloging and Classification recommending that a committee investigate the possibility of developing a multiple-copy order form to meet the needs of many librarians. ${ }^{2}$ Certainly it should not be an impossible task for some division of the ALA to accomplish.

The subject of librarian-bookseller relationships in the field of current books is a broad one. It is gratifying to observe the trend toward more discussion. Booksellers would like to meet more librarians, especially order librarians and would welcome them in their offices or shops that they might observe how the book trade operates and meet the people with whom they share mutual interests.

2 Journal of Cataloging and Classification, XI (1955), 106.

\section{List of Standard Lists Published}

In 1951 the Council of National Library Associations created the Committee for the Protection of Cultural and Scientific Resources to study proposals for the preservation of library, archival and museum materials in the event of atomic warfare.

After four meetings the Committee relinquished any ideas of broad-scale "protective" programs and agreed to recommend instead the systematic strengthening of resources on a regional basis to make each region self-sufficient in the books needed to continue research. To this end the representatives of the various library associations represented agreed to stimulate the production of "standard collection" lists which would aid in defining the desired level of resources.

As a first step toward the production of these lists it was agreed to prepare a list of "standard collection" lists. This has been published as: $A$ List of Checklists Used in Surveys of Library Book Collections. Prepared by the staff of the Library of Congress at the committee's request, this eighteen-page list may be requested from the committee's chairman, Scott Adams, National Institutes of Health Library, Bethesda 14, Maryland. 